\title{
Effects of dental acid etchants in oral epithelial cells
}

\author{
Do-kyeong Kim ${ }^{1 *}$, Jae-won Kwak², Ryeong-mi Jo², Da-som Jung ${ }^{2}$, Da-young Youn², Na-yeon $\mathrm{Oh}^{2}$, and Ji-hye Jang ${ }^{2}$
}

${ }^{1}$ Department of Dental Hygiene, Jeonju Kijeon College, Jeonju, Republic of Korea

${ }^{2}$ Department of Dental Hygiene, College of Medical Science, Konyang University, Daejeon, Republic of Korea

Phosphoric acid (P.A.; 37\%) can induce necrosis on the oral mucosa and cause the ulceration of periodontal tissue. However, most studies reported are clinical case studies, with few basic science studies on oral epithelial cells. Our study aimed to investigate the effects of dental acid etchants on oral epithelial cells. After treatment with dental acid etchants for the indicated periods ( 0 second, 10 seconds, 30 seconds, 1 minute, and 5 minutes), cell damage, including vacuoles, pyknosis, and karyolysis, was observed by hematoxylin-eosin staining. The percentage of cell damage significantly increased after 10 seconds of etchant application. Furthermore, as the etchantapplied time increased from 10 seconds, 3-(4, 5-dimethylthiazol-2-yl)-2, 5-diphenyltetrazolium bromide assay results showed that cell viability was significantly reduced. Dental acid etchants were diluted with distilled water at ratios of 1:2 (18.5\% P.A.) to 1:10 (3.7\% P.A.). After the application of 1:5 (7.4\% P.A.) diluted etchants, cells were enlarged, with some cells showing nuclear injury, including pyknosis. When treated with 1:2 (18.5\% P.A.) diluted etchants, karyorrhexis and vacuoles were observed. The percentage of damaged cells significantly increased after the application of 1:2 (18.5\% P.A.) diluted etchants. Moreover, cell viability significantly decreased in cells treated with 1:5 (7.4\% P.A.) and 1:2 (18.5\% P.A.) diluted etchants. This study examined the effects of dental acid etchants on oral epithelial cells as a basic experimental study in vitro and demonstrated the risks of dental acid etchants. Therefore, dentists and dental hygienists should pay strict attention to the handling of acid etchants during restoration and orthodontic treatments.

Key Words: Cell viability, Dental acid etchants, Oral mucosa, Phosphoric acid

(c) This is an open-access article distributed under the terms of the Creative Commons Attribution Non-Commercial License (http://creativecommons.org/licenses/by-nc/4.0) which permits unrestricted noncommercial use, distribution, and reproduction in any medium, provided the original work is properly cited.

\section{INTRODUCTION}

Dental acid-etchants demineralize the tooth surface and increase dentin permeability to improve mechanical adhesion between bonding agents and the tooth structure. Furthermore, it facilitates the penetration as the first step in aesthetic restoration [1].

When enamel etching was introduced in 1955, the recommended time for $85 \%$ phosphoric acid (P.A.) etching was 30 seconds [2]. Recently, most manufacturers of dental acid-etchants have recommended 15 to 30 seconds when $32 \%$ to $40 \%$ P.A. is used $[1,3]$. This is to minimize tooth damage caused by dental acid-etchants without compromising the adhesive performance [4]. In the total etch technique, dentin is etched with P.A. and then the etchants must be rinsed off immediately after 15-30 seconds of application time $[1,4]$. Inadequate rinsing of dental acidetchants or remaining dental acid-etchants can cause the

Received October 4, 2019; Revised November 20, 2019; Accepted November 23, 2019

*Corresponding author: Do-kyeong Kim, Department of Dental Hygiene, Jeonju Kijeon College, 267 Jeonjucheonseo-ro, Wansan-gu, Jeonju 54989 , Republic of Korea.

Tel: +82-63-280-5208, Fax: +82-63-286-9995, E-mail: dkkim2908@naver.com

Copyright $\odot$ 2019, Oral Biology Research Institute 
problems, including chemical burning, irritation and inflammation, intra and extra-orally.

P.A. (37\%) can lead to necrosis in the oral mucosa and ulcerative lesions of the periodontal tissue $[5,6]$. These lesions can spread from the superficial to the deeper layers and can be accompanied by difficulty of swallowing and pronunciation and burning depending on the location. Furthermore, iatrogenic chemical burn caused by P.A. can cause itching, burning sensations, as well as vesicular and corrosive lesions on facial skin [7].

Some studies have been conducted on the hazards of dental acid-etchants (37\% P.A.) to the skin [7] and oral mucosa $[5,6]$. However, most of them were clinical case studies and there are few basic studies on oral epithelial cells. Therefore, our study aimed to investigate the effect of dental acid-etchants on oral epithelial cells by comparing the degree of cell damage and cell viability in oral epithelial cells with application time and concentration of dental acid-etchants.

\section{MATERIALS AND METHODS}

\section{Cell cultures}

Immortalized human oral keratinocytes (IHOK) transfected with human papilloma virus 16 E6/E7 were used [8]. The cells were grown in F medium, which is consisting of Dulbecco's Modified Eagles Medium (Gibco BRL, Grand Island, NY, USA) and Ham's Nutrient Mixture-F12 (Gibco BRL) at a ratio of 3:1, supplemented with $10 \%$ fetal bovine serum and $1 \%$ penicillin/streptomycin. The cells were maintained in an incubator at $37^{\circ} \mathrm{C}$, with an atmosphere of $5 \% \mathrm{CO}_{2}$. The cell culture medium was changed every 3 days.

\section{Hematoxylin-eosin staining}

To observe the morphological changes caused by dentalacid etchants, hematoxylin-eosin (H\&E) staining was performed. IHOK cells $\left(5 \times 10^{4}\right)$ were seeded in chamber slides (Lab-Tek Chamber slide; Nalge Nunc, Roskilde, Denmark) and were treated with dental acid-etchant (eDent, Seoul, Korea) for the indicated time or concentration. Briefly, the cells were washed with phosphate-buffered saline and then fixed in 95\% ethanol for an hour. After hydration and dehydration, the cells were stained with H\&E. After H\&E staining, the nucleus appears deep purple, and the cytoplasm appears red or pink by light microscopy.

\section{Cell damage analysis}

To quantify cell damaged by the dental acid-etchants, the damaged cells were counted in images of 5 random microscopic fields ( $\times 400$ magnification) after H\&E staining. Cell damage contains both irreversible cell injuries, including karyorrhexis, pyknosis, karyolysis and membrane destruction, and reversible cell injuries, including vacuole and cell swelling (enlargement). The percentage of damaged cells was calculated in the total number of cells.

\section{Cell viability and cytotoxicity assay}

To identify the cytotoxic effect of dental acid-etchants on epithelial cell, a 3-(4, 5-dime-thylthiazol-2-yl)-2, 5-diphenyltetrazolium bromide (MTT) assay was performed. In brief, the cells $\left(1 \times 10^{5}\right)$ were seeded in to 24 well plates and different concentration (non-treated, undiluted, dilution ratios of 1:2, 1:5, and 1:10) of dental acid-etchants were applied for different times (0 second, 10 seconds, 30 seconds, 1 minute, and 5 minutes). After cell stabilization for 24 hours, MTT solution (Duchefa Biochemie, Haarlem, Netherlands) was added to each well and incubated for 4 hours at $37^{\circ} \mathrm{C}$. After removing the MTT solution, dimethyl sulfoxide (Duchefa Biochemie) was added to dissolve the formazan dye crystals. The optical density was measured at a wavelength of $540 \mathrm{~nm}$ by microplate reader (Bio-Rad, Hercules, CA, USA). The percentage of damaged cells the experimental group was normalized to each control.

\section{Statistical analysis}

All statistical analyses were performed by SPSS ver. 20.0 (IBM Corp., Armonk, NY, USA). Mann-Whitney U-tests were used to compare between control and experimental groups. Each experiment was performed at least in triplicate. The results were reported as the mean \pm standard 
deviation. A value of $p<0.05$ was considered statistically significant.

\section{RESULTS}

\section{Effect of dental acid-etchant application time on cell damage and viability of oral epithelial cells}

To examine the effect of application time on cell damage caused by dental acid-etchants, we first observed morphological changes in the oral epithelial cells. After treatment with dental acid-etchants for the indicated time (0 second, 10 seconds, 30 seconds, 1 minute, 5 minutes), H\&E staining was performed (Fig. 1A). The concentration of dental acid-etchants is fixed in 37\% P.A., which commonly used in clinical practice. In the first 10 seconds of application, the dental acid-etchants showed remarkable cell damage, including vacuoles in some cells, pyknosis, and karyolysis. In 30 seconds of etchant application, almost cells showed cell injury in the nucleus. In one minute of application, the cells were enlarged with nuclear injury and subsequent membrane destruction. Consistently, the percentage of cell damage significantly was increased from 10 seconds of etchant application (Fig. 1B). These results demonstrated that cell damage was induced by dental acid-etchant, even for a short time.

To further investigate cell viability by different application times of dental acid-etchants, MTT assays were performed (Fig. 1C). After treatment with dental acid-etchants for the indicated times ( 0 second, 10 seconds, 30 seconds, 1 minute, and 5 minutes), it was removed and the cells were regrown in fresh culture medium for 24 hours. Compared to control (0 second), cell viability was decreased 4.29fold $(23.30 \% \pm 16.16 \%)$ in cells treated with etchants for 10

\section{A}
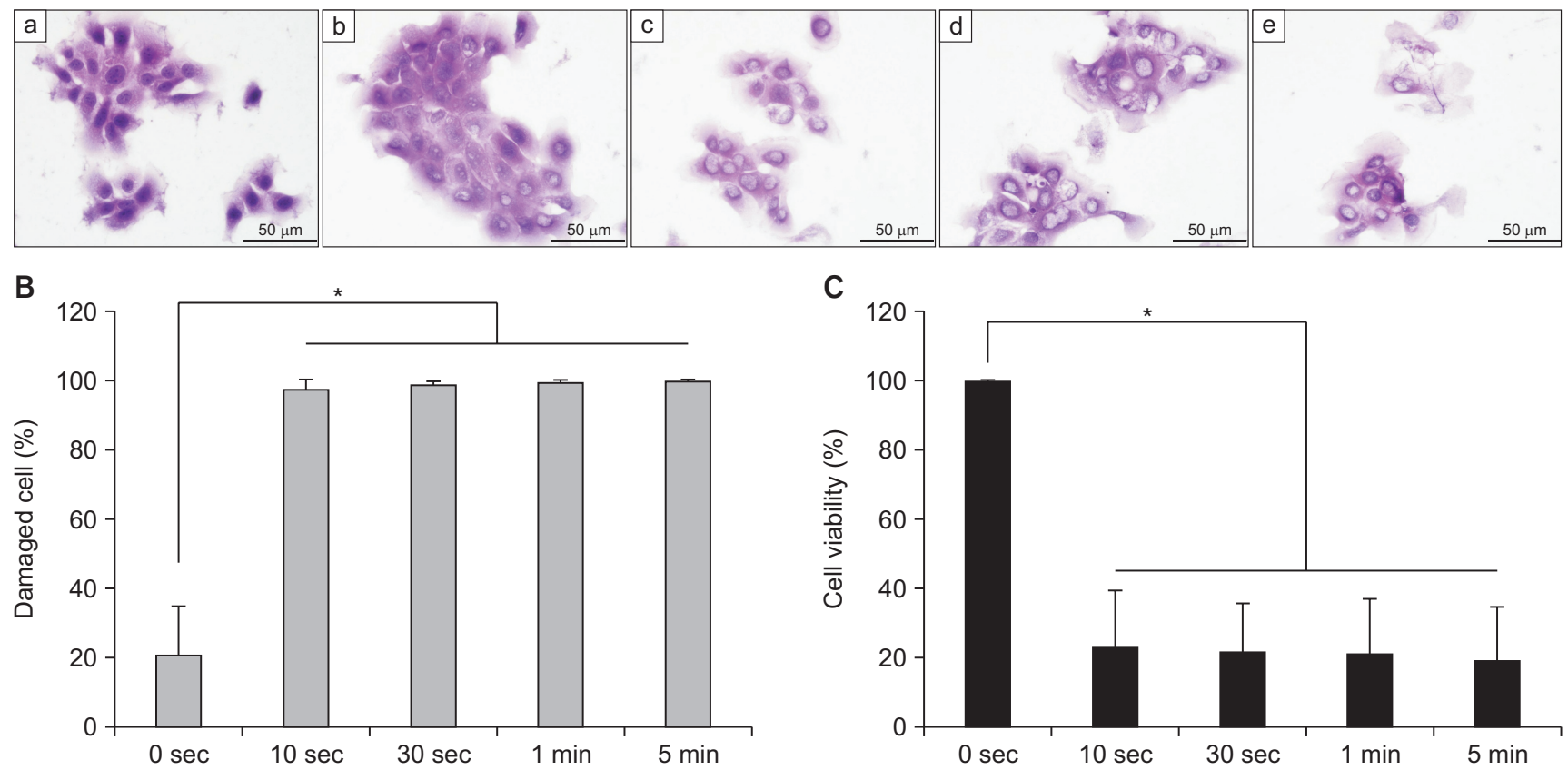

Fig. 1. Effect of dental acid-etchant application time on cell damage and viability in oral epithelial cells. (A) Morphology of oral epithelial cells by etchant gel application time. After application of dental acid-etchants (37\% phosphoric acid) for the indicated times ([a] 0 second, [b] 10 seconds, [c] 30 seconds, [d] 1 minute and [e] 5 minutes), the cells were stained with hematoxylin-eosin. Representative images are shown (scale bar 50 $\mu \mathrm{m}$, magnification $\times 400$ ). (B) Cell damage by etchant gel application time. Cell damage includes both nuclear and membrane injuries. All damaged cells were counted and then bar graph shows the relative percentage of cells damaged by etchant gel application time. (C) Cell viability by application time of dental acid-etchant in oral epithelial cells. Immortalized human oral keratinocytes cells were seeded into 24-well plates and then treated with $37 \%$ phosphoric acid (dental acid-etchant) for the indicated times. The cells were re-grown in fresh medium (10\% fetal bovine serum $+1 \%$ penicillin/streptomycin in P medium) for 24 hours and then 3-(4, 5-dime-thylthiazol-2-yl)-2, 5-diphenyltetrazolium bromide assays were performed. The bar graph shows the cell viability percentage relative to the control ( 0 second). ${ }^{*} p<0.05$ by Mann-Whitney $\mathrm{U}$-test. 
seconds. As the application time increased, the cell viability decreased 4.55 -fold $(21.96 \% \pm 13.45 \%)$, 4.69-fold $(21.32 \%$ $\pm 15.54 \%)$ and 5.15 -fold $(19.44 \% \pm 15.00 \%)$ at 30 seconds, 1 minute, and 5 minutes, respectively $(p=0.014)$. As the etchant-applied time increased, cell viability was significantly reduced.

Taken together, dental acid-etchants (37\% P.A.) induced irreversible cell injury, including karyolysis and pyknosis, in time as short as 10 seconds.

\section{Effects of dental acid-etchant concentration on cell damage and viability of oral epithelial cells}

Next, we examined the effects of different dental acidetchants concentrations on cell damage.
Morphological changes were observed by H\&E staining in oral epithelial cells (Fig. 2A). To clearly observe the cell morphological damage and cell viability, dental acidetchants were applied for 1 minute. Dental acid-etchants were diluted with distilled water at ratios of 1:2 (18.5\% P.A.) to $1: 10$ (3.7\% P.A.). When the cells were treated with etchants diluted $1: 10$ ratio (3.7\% P.A.), there were no visible morphological changes compared to control cells (non-treated). After the application of etchants diluted 1:5 (7.4\% P.A.), the cells were enlarger than the control cells, and some cells showed nuclear injury, including pyknosis. When treated with etchants diluted 1:2 (18.5\% P.A.), karyorrhexis and vacuoles were shown in the cells. Consistently, the percentage of damaged cells was significantly increased from the application of etchants diluted 1:2
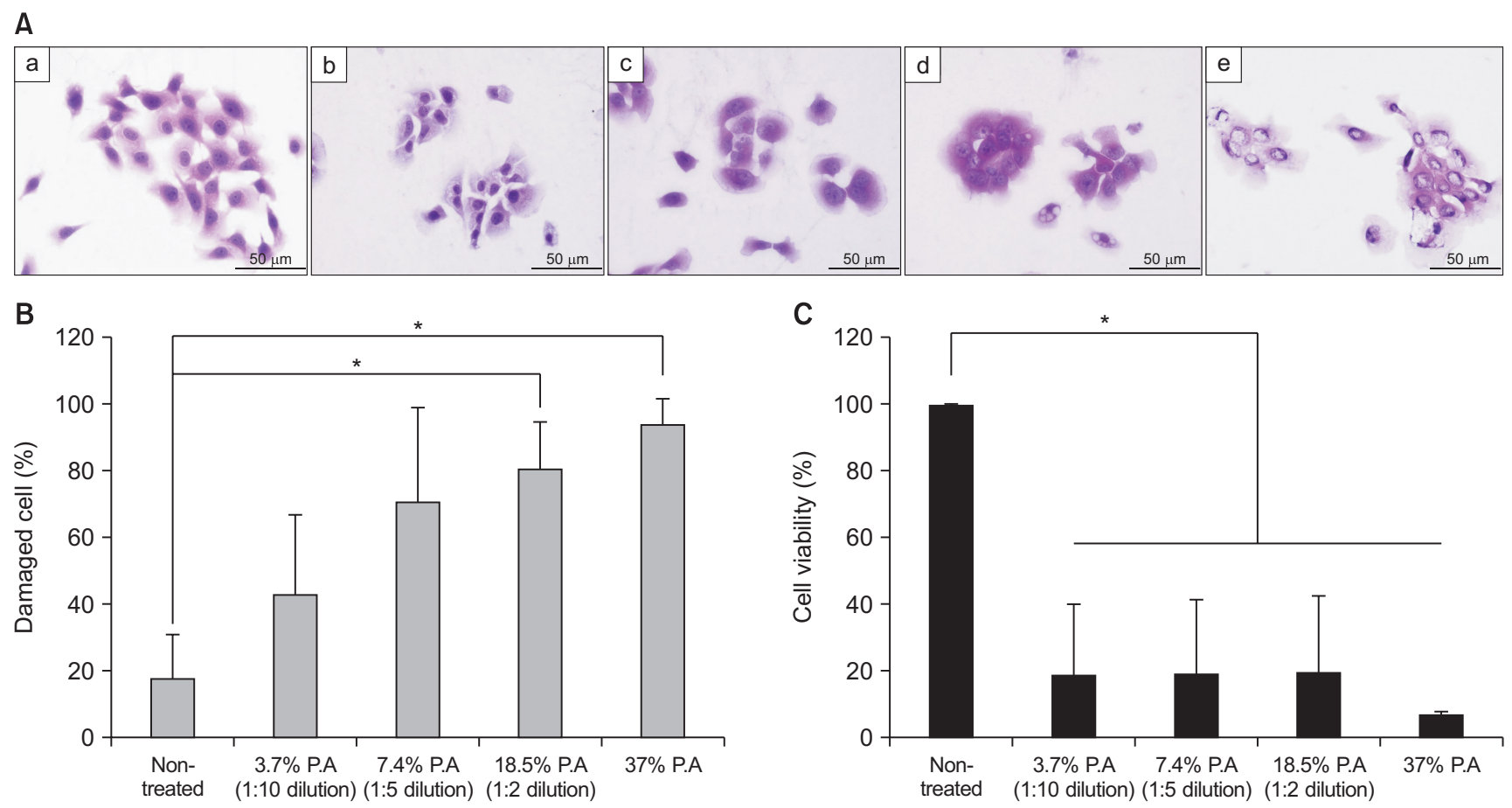

Fig. 2. Effect of dental acid-etchant concentration on cell damage and viability in oral epithelial cells. (A) Morphology of oral epithelial cells by etchant gel concentration. After application with each concentration ([a] non-treated, [b] 3.7\% phosphoric acid [P.A.; 1:10 dilution], [c] 7.4\% P.A. [1:5 dilution], [d] 18.5\% P.A. [1:2 dilution], and [e] 37\% P.A. [undiluted dental-etchant]) for 1 minute, the cells were fixed and stained with hematoxylin-eosin. Representative images are shown (scale bar $50 \mu \mathrm{m}$, magnification $\times 400)$. (B) Cell damage by etchant gel application time. Cell damage includes both nuclear and membrane injuries. All damaged cells were counted, and the bar graph shows the percentage of damage cell by etchant gel application time relative to the control cells. (C) Cell viability by concentration of dental acid-etchant in oral epithelial cells. Immortalized human oral keratinocytes cells were seeded into 24 -well plates and then treated with the indicated concentration (dilution ratio) of dentaletchant. The cells were re-grown in fresh medium (10\% fetal bovine serum $+1 \%$ penicillin/streptomycin in P medium) for 24 hours and $3-(4$, 5-dime-thylthiazol-2-yl)-2, 5-diphenyltetrazolium bromide assays were performed. The bar graph shows the percentage of cell viability relative to the control cells (non-treated). P.A., phosphoric acid. ${ }^{*} p<0.05$ by Mann-Whitney U-test. 
(18.5\% P.A.) $(p<0.05)$ (Fig. 2B). Compared to nontreated cells, cell injury was increased 2.44 -fold $(42.79 \% \pm 23.49 \%)$ in cells treated with $3.7 \%$ P.A. (1:10 diluted etchants) and 4.01-fold $(70.45 \% \pm 27.86 \%)$ in cells treated with $7.4 \%$ P.A. (1:5 diluted etchants), although it is not significant. When the cells were treated with more 18.5\% P.A. (1:2 diluted etchants), the percentage of damaged cells increased 4.58fold $(80.37 \% \pm 13.89 \%)(p<0.05)$. Collectively, as the concentration of P.A. increased, the number of damaged cells increased. In particular, oral epithelial cells showed that increased cell injury in the nucleus and cell membrane when they were treated with dental acid-etchants containing more than $18.5 \%$ P.A.

Following treatment with each concentration of dental acid-etchant, we observed cell viability. After treatment with dental acid-etchants, the cells were stabilized for 24 hours and then MTT assays were performed (Fig. 2C). When the cells were treated with diluted etchants at a ratio of 1:10, cell viability decreased 5.33 -fold (18.75\% $\pm 20.98 \%)$ compared to control (non-treated). Moreover, cell viability decreased 5.17 -fold $(19.35 \% \pm 21.93 \%)$ in cells treated with 1:5 diluted etchants (7.4\% P.A.) and 5.07-fold (19.72\%土 $23.01 \%)$ with $1: 2$ diluted-etchant (18.5\% P.A.) ( $p=0.014)$. Thus, when oral epithelial cells were treated with dental acid-etchants containing more than 3.7\% P.A., the cell survival rate was significantly reduced.

\section{DISCUSSION}

Dental acid-etchants commonly used clinically are highly acidic, containing 37\% P.A., and contact with human tissues can cause tissue necrosis or chemical burns [6,7]. Intra- and extra-oral tissues are at greater risk of exposure to dental acid-etchants. In severe cases, the gingiva recessed and necrotized by etchants was treated with subepithelial connective tissue graft [5]. The chemical burns of facial skin and tongue that occurred during composite restoration and orthodontic treatment [6,7]. However, most reports were clinical research and few studies have examined the effects of oral epithelial cells by direct contact with dental acid-etchants.

We investigated morphological changes, cell damage, and cell viability to identify the effects by dental acid- etchants on oral epithelial cells. First, we identified the effects by dental acid-etchant's application time on oral epithelial cells (Fig. 1). The concentration of dental-acidetchants was fixed to $37 \%$ P.A., which commonly used clinically. In the etch technique, dental acid-etchants must be rinsed with water immediately after 15-30 seconds, which is application time in manufacturer's instruction. At this time, inadequate rinse can remain the dental acidetchants with various diluted concentration of P.A., and then we hypothesized that it can irritate on oral soft tissues. Seconds, we examined the effects by dental acid-etchant' $\mathrm{s}$ various diluted concentrations on oral epithelial cells (Fig. 2). When dental acid-etchants were applied to oral epithelial cells for 10 seconds or the etchant contained at least 18.5\% P.A., vacuoles and nuclear damage were observed in cells, including karyolysis and karyorrhexis. Furthermore, cell injuries were remarkedly shown with increasing application time and concentration. Among the cell morphological changes, vacuole formation is an early stage of cell damage and can occur in different types of cell death, such as autophagy, apoptosis, and necrosis [9,10]. Also, nuclear damage, such as pyknosis and karyolysis, is caused by cell necrosis [11]. Consistently, the cell survival rate was significantly reduced by dental acid-etchant application, even though the etchants were applied for as short as 10 seconds or a P.A. concentration as low as $3.7 \%$.

The dentin adhesive system is one of the fastest developing dental materials and can classify to the etch \& rinse system and self-etching system [3,12]. Self-etching adhesives have advantages, such as reducing the damage to oral soft tissues and contamination to the surrounding, and short chair time, because there is no acid corrosion and rinse. However, self-etching adhesives can induce cell shrinkage, irregular cell morphology, cytotoxicity, and necrosis [13-15]. Consistent with our results, cell viability was decreased, even though the self-etching adhesives were applied at low concentrations.

Acid-mediated corrosion can maximize the ability for adhesion to dentin $[4,16]$. Both dental acid-etchants and self-etching adhesives can cause irreversible injury to the cells when they come in direct contact with the cells at low concentrations and for short application times. To maximize the function of dental acid-etchants and minimize the 
adverse effects on soft tissue, it is important to prevent the inflow of dental acid-etchants into soft tissues by exposing only the treatment area. First, the dentist should thoroughly isolate the treatment area from soft tissue, by using a rubber dam or cotton roll and use of gel-type dental acidetchants. For dental hygienists, it is important to use strong suction or a large size suction tip to eliminate completely acid-etchants so that residual acid-etchants do not irritate the oral mucosa.

This study examined that effects of dental acid-etchants on oral epithelial cells as a basic experimental study in vitro and specifically showed the risk of dental acid-etchants. Therefore, dentists and dental hygienists should pay strict attention to the handling of acid-etchants during restoration and orthodontic treatment. Furthermore, we expect that this study will provide as the basis for the development of biocompatible acid-etchants and dentin adhesive systems in the future.

\section{CONFLICTS OF INTEREST}

The authors declare that they have no competing interests.

\section{ORCID}

$$
\begin{aligned}
& \text { Do-kyeong Kim } \\
& \text { https://orcid.org/0000-0002-5154-9613 } \\
& \text { Jae-won Kwak } \\
& \text { https://orcid.org/0000-0002-8055-4542 } \\
& \text { Ryeong-mi Jo } \\
& \text { https://orcid.org/0000-0002-7157-0460 } \\
& \text { Da-som Jung } \\
& \text { https://orcid.org/0000-0001-7442-1084 } \\
& \text { Da-young Youn } \\
& \text { https://orcid.org/0000-0002-2737-6580 } \\
& \text { Na-yeon Oh } \\
& \text { https://orcid.org/0000-0003-1809-4925 } \\
& \text { Ji-hye Jang } \\
& \text { https://orcid.org/0000-0001-5917-2374 }
\end{aligned}
$$

\section{REFERENCES}

1. Jeong WG, Gang YM, Gung HS, Gim DH, Gim RY, Gim AJ, Gim EJ, Gim HE, Mun HJ, Bak SS, Bak JH, Bae SS, Seong GY, Song JJ, Sim SS, An SH, Yang SY, U SH, Yu JS, Yun MS, Yun HY, Yun HS, Lee MO, Lee SY, Lee SS, Lee Y, Lee H, Lee HK, Im GO, Im SY, Jeong MH, Jeong UJ, Jo MS, Jo HE, Ji MG, Choe MH, Hong SM, Hwang SH. Principles and practice of conservative dentistry. 4th ed. Seoul: Daehan Narae Publishing, Inc.; 2016.

2. Buonocore MG. A simple method of increasing the adhesion of acrylic filling materials to enamel surfaces. J Dent Res 1955;34:849-853. doi: 10.1177/00220345550340060801.

3. Sofan E, Sofan A, Palaia G, Tenore G, Romeo U, Migliau G. Classification review of dental adhesive systems: from the IV generation to the universal type. Ann Stomatol (Roma) 2017;8:1-17. doi: 10.11138/ads/2017.8.1.001.

4. Lopes GC, Thys DG, Klaus P, Oliveira GM, Widmer N. Enamel acid etching: a review. Compend Contin Educ Dent 2007;28:18-24; quiz 25, 42.

5. Akman AC, Demiralp B, Güncü GN, Kiremitçi A, Sengün D. Necrosis of gingiva and alveolar bone caused by acid etching and its treatment with subepithelial connective tissue graft. J Can Dent Assoc 2005;71:477-479.

6. Rao R. Report of etchant induced oral chemical burna rare incidence. Int J Adv Res 2018;6:257-260. doi: 10.21474/IJAR01/6212.

7. Park JH, Shin HJ, Park SH, Kim JW, Cho KM. Iatrogenic chemical burn on facial skin by 37\% phosphoric acid etchant. J Korean Acad Conserv Dent 2009;34:38-41. doi: 10.5395/JKACD.2009.34.1.038.

8. Lee HJ, Guo HY, Lee SK, Jeon BH, Jun CD, Lee SK, Park MH, Kim EC. Effects of nicotine on proliferation, cell cycle, and differentiation in immortalized and malignant oral keratinocytes. J Oral Pathol Med 2005;34:436-443.

9. Schauer A, Knauer H, Ruckenstuhl C, Fussi H, Durchschlag M, Potocnik U, Fröhlich KU. Vacuolar functions determine the mode of cell death. Biochim Biophys Acta 2009;1793:540-545. doi: 10.1016/j.bbamcr.2008.11.006.

10. Nakajima A, Kurihara H, Yagita H, Okumura K, Nakano H. Mitochondrial extrusion through the cytoplasmic vacuoles during cell death. J Biol Chem 2008;283:24128-24135. doi: 10.1074/jbc.M802996200.

11. Kumar V, Abbas AK, Aster JC, Robbins SL. Robbins basic pathology. 9th ed. Philadelphia: Elsevier/Saunders; 2013;xii, 910.

12. Lawson NC, Robles A, Fu CC, Lin CP, Sawlani K, Burgess JO. Two-year clinical trial of a universal adhesive in total-etch and self-etch mode in non-carious cervical lesions. J Dent 2015;43:1229-1234. doi: 10.1016/ j.jdent.2015.07.009.

13. Rhee CH, Kim IR, Kim GC, Kim SS, Son WS. In vitro 
cytotoxicity of self-etching primers. Korean J Orthod 2006;36:422-433.

14. Pupo YM, Bernardo CFF, de Souza FFFA, Michél MD, Ribeiro CNM, Germano S, Maluf DF. Cytotoxicity of etchand-rinse, self-etch, and universal dental adhesive systems in fibroblast cell line 3T3. Scanning 2017;2017:9650420. doi: $10.1155 / 2017 / 9650420$.

15. Kusdemir M, Gunal S, Ozer F, Imazato S, Izutani N, Ebisu S,
Blatz MB. Evaluation of cytotoxic effects of six self-etching adhesives with direct and indirect contact tests. Dent Mater J 2011;30:799-805. doi: 10.4012/dmj.2011-046.

16. Lee AR, Kim HS, Ku HW, Hwang HK, Jo HH, Min JB. Evaluation of etched enamel using quantitative light-induced fluorescence. Oral Biol Res 2018;42:10-15. doi: 10.21851/ obr.42.01.201803.10. 